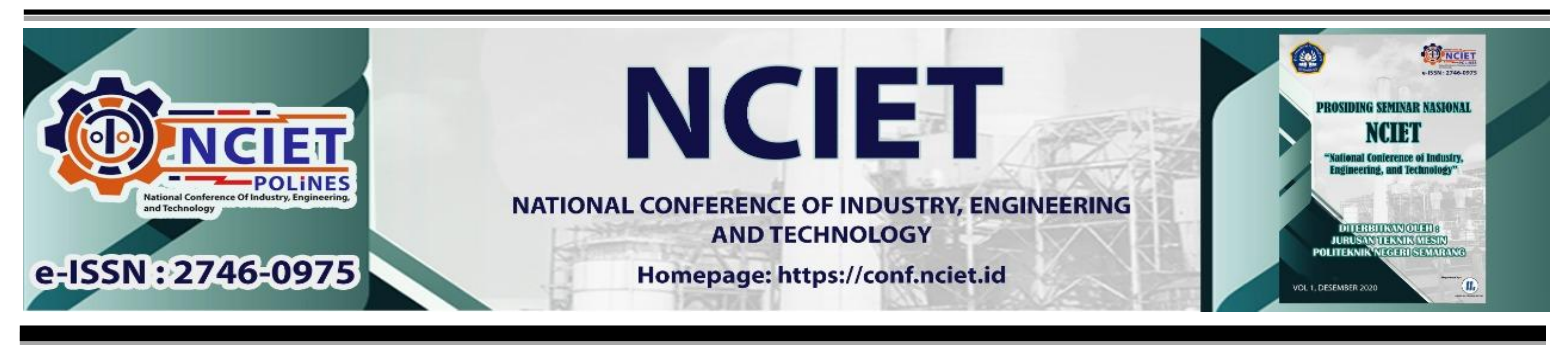

Prosiding Seminar Nasional NCIET Vol.1 (2020) B312-B316

$1^{\text {st }}$ National Conference of Industry, Engineering and Technology 2020,

Semarang, Indonesia.

\title{
PENGARUH VARIASI BEBAN TERHADAP EFISIENSI \\ HIGH PRESSURE SYSTEM HEAT RECOVERY STEAM GENERATOR 2.3 PEMBANGKIT LISTRIK TENAGA GAS DAN UAP TAMBAK LOROK PT. INDONESIA POWER SEMARANG PGU
}

\author{
Wahyono*, Ardi Candra M \\ Jurusan Teknik Mesin, Politeknik Negeri Semarang \\ Jl. Prof. H. Soedarto S.H., Tembalang, Semarang, 50275 \\ *E-mail: wahyono.polines@gmail.com
}

\begin{abstract}
Abstrak
Heat Recovery Steam Generator (HRSG) adalah sebuah alat dalam pembangkit listrik tenaga gas dan uap dengan operasi combined cycle yang memanfaatkan gas buang dari turbin gas untuk memanaskan air pada pipa-pipa yang berada di dalamnya supaya dihasilkan uap kering yang mampu memutar turbin uap. Penelitian ini bertujuan untuk mengetahui pengaruh variasi beban terhadap nilai efisiensi High Pressure System Heat Recovery Steam Generator (HP HRSG) 2.3 dilakukan pada tanggal 18 Agustus 2019. Besar efisiensi dapat digunakan sebagai acuan pengoperasian HRSG guna meningkatkan produksi listrik. Hasil analisa perhitungan data operasional maka diperoleh nilai efisiensi pada saat beban $90 \mathrm{MW}$ sebesar 52,07\%, saat beban 80 MW sebesar 49,59\%, dan saat beban 70 MW sebesar 48,19\%. Data menunjukkan efisiensi HP HRSG semakin tinggi saat beban pada gas turbine generator (GTG) bertambah besar hal tersebut dikarenakan panas gas buang yang dihasilkan besar saat beban GTG besar pula.
\end{abstract}

Kata Kunci: Heat Recovery Steam Generator; Efisiensi; Beban

\section{PENDAHULUAN}

Seiring dengan meningkatnya pertumbuhan penduduk dan pertumbuhan ekonomi,maka kebutuhan energi listrik juga mengalami peningkatan. Melihat kondisi tersebut, maka perlu adanya suatu peningkatan dalam produksi tenaga listrik. Produksi yang dimaksud tidak hanya menitik beratkan pada kapasitas daya yang mampu dihasilkan tetapi juga perekayasaan mesin, sistem operasi dan pemeliharaan guna mempertahankan efisiensi produksi listrik suatu pembangkit listrik. Pusat Pembangkit Tenaga Gas dan Uap merupakan suatu pusat pembangkit energi thermal yang memiliki peranan penting dalam memproduksi pembangkit listrik.

PLTGU merupakan pusat pembangkit energi listrik yang menggunakan siklus gabungan (Combined Cycle Power Plant) yang terdiri dari siklus Brayton dan siklus Rankine dengan 
perantara Heat Recovery Steam Generator (HRSG). Secara sederhana PLTGU gabungan antara GTG dan STG dimana energi panas dari gas buang turbin gas yang masih tinggi temperaturnya digunakan untuk mengubah air menjadi uap kering yang digunakan sebagai fluida kerja turbin uap

Heat Recovery Steam Generator (HRSG) merupakan bagian penting dalam siklus gabungan PLTGU. Heat Recovery Steam Generator (HRSG) bekerja dengan memanfaatkan panas dari gas buang turbin gas.temperatur gas buang masuk HRSG sekitar $555^{\circ} \mathrm{C}$ dan sekitar $150^{\circ} \mathrm{C}$ pada cerobong pembuangan.

Dalam pelaksanaan kerja praktik ini penulis ditempatkan di bagian Pemeliharaan Mekanik. Kerja praktik yang telah dilaksanakan di PT Indonesia Power Semarang PGU memberikan banyak pengetahuan dan pengalaman bagi penulis dalam berbagai disiplin ilmu dan pengetahuan tentang dunia kerja. Dari sekian banyak pengetahuan yang penulis dapatkan selama kerja praktik, maka didalam laporan ini penulis membahas mengenai "Pengaruh Variasi Beban Terhadap Efisiensi High Pressure System Heat Recovery Steam Generator 2.3 PT Indonesia Power Semarang PGU”.

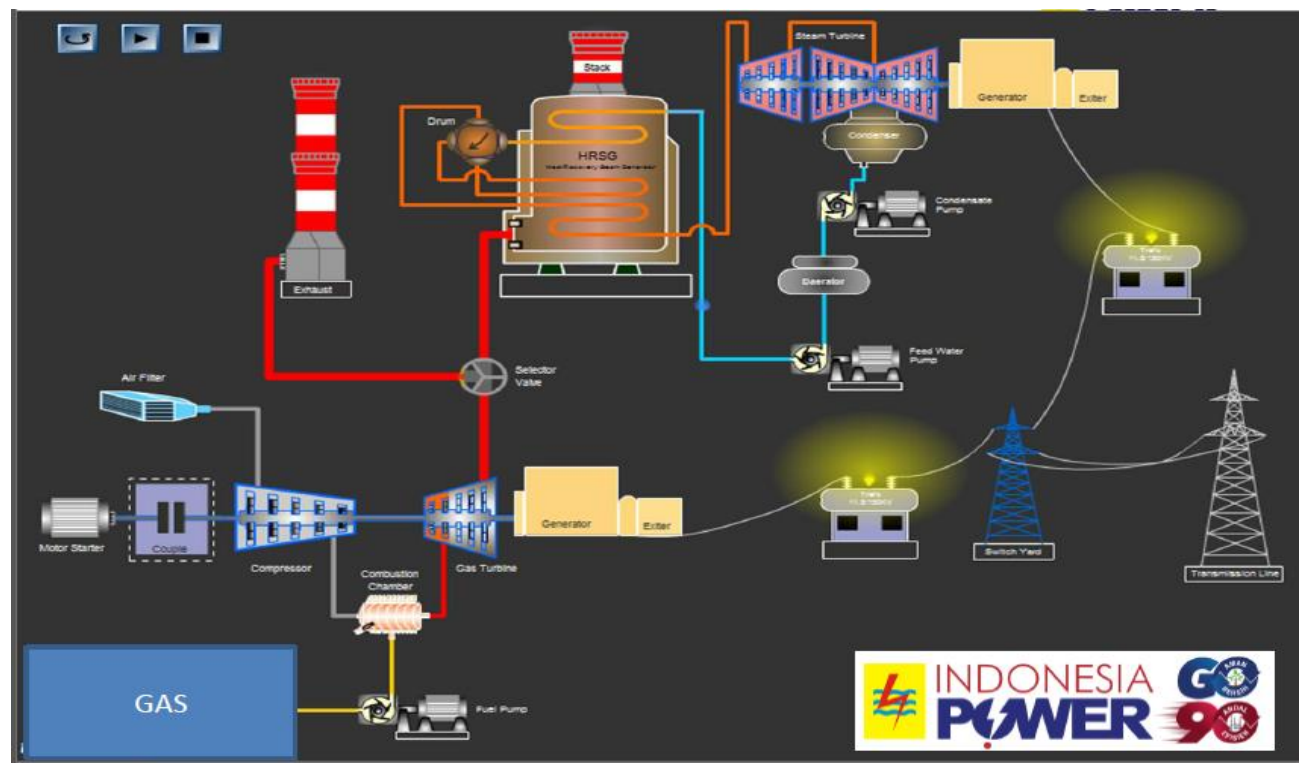

Gambar 1. Proses Produksi Listrik PLTGU

\section{METODE PENELITIAN}

Penelitihan ini dilaksanakan di PT Pembangkit Listrik PGU. Waktu pelaksanaan penelitihan yaitu mulai tanggal 1 Agustus 2019 sampai dengan 31 Agustus 2019. 


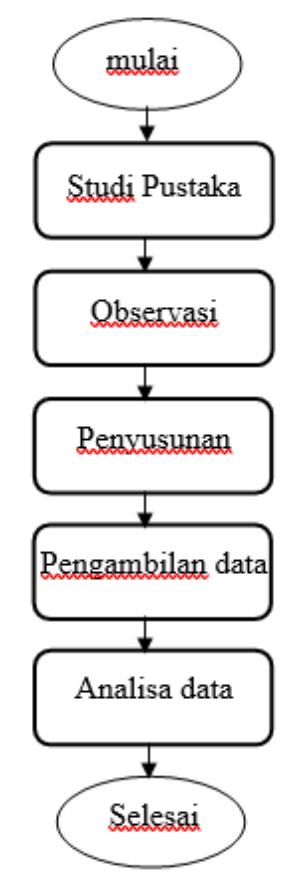

Gambar 4. Alur Penelitian

1. Studi Pustaka Menambah wawasan / pengetahuan mengenai tema penelitian dengan menelaah literatur-literatur yang berhubungan dan bersesuaian.

2. Observasi Lapangan Dengan cara melakukan pengamatan secara sistematis mengenai hal-hal yang berkaitan dengan HRSG di PLTGU PT. Indonesia Power Semarang PGU.

3. Bimbingan dan konseling Bertujuan untuk mendapatkan tambahan pengetahuan dan masukan dari pembimbing serta koreksi atas kekurangan-kekurangan yang terjadi.

\section{HASIL DAN PEMBAHASAN}

Tabel 4.1 Data Operasional

\begin{tabular}{|c|c|c|c|c|c|}
\hline \multirow{2}{*}{ No } & \multirow{2}{*}{ Item } & \multirow{2}{*}{ Satuan } & \multicolumn{3}{|c|}{ Variasi Beban } \\
\cline { 4 - 6 } & & & $94 \mathrm{MW}$ & $80 \mathrm{MW}$ & $70 \mathrm{MW}$ \\
\hline 1. & $\dot{\mathrm{M}}_{f}$ & $\mathrm{~kg} / \mathrm{s}$ & 5,9 & 5,3 & 4,8 \\
\hline 2. & $G H V$ & $\mathrm{Kj} / \mathrm{kg}$ & 54144,715 & 54144,715 & 54144,715 \\
\hline 3. & $\dot{\mathrm{M}}_{H P E c o}$ & $\mathrm{Kg} / \mathrm{s}$ & 40,83 & 37,36 & 32,64 \\
\hline 4. & $P_{H P E c o}$ & $\mathrm{Bar}$ & 119 & 121 & 123 \\
\hline 5. & $T_{H P E c o}$ & ${ }^{\circ} \mathrm{C}$ & 157 & 158 & 159 \\
\hline 6. & $\dot{\mathrm{M}}_{H P S H}$ & $\mathrm{Kg} / \mathrm{s}$ & 40,5 & 35,86 & 32,13 \\
\hline 7. & $P_{H P S H}$ & $\mathrm{Bar}$ & 45,6 & 52,8 & 44,6 \\
\hline 8. & $T_{H P S H}$ & ${ }^{\circ} \mathrm{C}$ & 515 & 516 & 501 \\
\hline
\end{tabular}


Tabel 4.2 Data Perhitungan GTG 2.3

\begin{tabular}{|c|c|c|c|c|c|}
\hline \multirow{2}{*}{ No } & \multirow{2}{*}{ Item } & \multirow{2}{*}{ Satuan } & \multicolumn{3}{|c|}{ Variasi Beban } \\
\cline { 4 - 6 } & & & $94 \mathrm{MW}$ & $80 \mathrm{MW}$ & $70 \mathrm{MW}$ \\
\hline 1. & $\mathrm{~h}_{\text {inlet }}$ & $\mathrm{kJ} / \mathrm{s}$ & 669,36 & 673,77 & 678,192 \\
\hline 2. & $\mathrm{~h}_{S H}$ & $\mathrm{Kj} / \mathrm{s}$ & 3474,16 & 3468,73 & 3442,94 \\
\hline 3. & LGN & $\mathrm{KW}$ & 1588,6 & 1352 & 1183 \\
\hline 4. & Rugi Konsumsi Panas & - & 0,9835 & 0,9835 & 0,9835 \\
\hline 5. & Rugi-rugi Turbin & $\mathrm{KW}$ & 966,947 & 966,947 & 966,947 \\
\hline
\end{tabular}

Tabel 4.3 Hasil Perhitungan Efisiensi

\begin{tabular}{|c|c|c|c|}
\hline No & Variasi beban & Efisiensi HP HRSG & $\dot{\mathrm{M}}_{f g}$ \\
\hline 1 & $94 \mathrm{MW}$ & $52,07 \%$ & 5,9 \\
\hline 2 & $80 \mathrm{MW}$ & $49,59 \%$ & 5,3 \\
\hline 3 & $70 \mathrm{MW}$ & $48,19 \%$ & 4,8 \\
\hline
\end{tabular}

\section{Perhitungan efisiensi High Pressure System HRSG pada beban 94MW :}

$$
\begin{aligned}
\eta_{H P H R S G} & =\frac{\left[\left(\dot{\mathrm{M}}_{H P} X h_{H P}\right)-\left(\dot{\mathrm{M}}_{H P} X h_{\text {inlet }}\right]\right.}{\left[0.9835\left(\dot{\mathrm{M}}_{f g} \times G H V\right)-\left(W_{G T G}\right)-966.947-L G N\right]} \times 100 \% \\
\eta_{H P H R S G} & =\frac{[(40,5 \times 3474,16)-(40,83 \times 669,36)]}{[0.9835(5,9 \times 54144,715)-94000-966.947-1588,6]} \times 100 \% \\
\eta_{H P H R S G} & =\frac{113.373,51}{217.787,01} \times 100 \% \\
\eta_{H P H R S G} & =52,07 \%
\end{aligned}
$$

Pada tabel 4.3 memperlihatkan pengaruh variasi beban terhadap efisiensi High Pressure Heat Recovery Steam Generator 2.3, terlihat bahwa semakin besar beban yang ditanggung GTG maka efisiensi HP HRSG juga semakin besar hal ini dikarenakan panas yang dihasilkan dari sisa gas buang GTG juga semakin besar.

Pada tabel 4.3 terlihat bahwa perubahan beban pada GTG juga mempengaruhi konsumsi bahan bakar, dimana semakin besar beban yang ditanggung GTG maka konsumsi bahan bakar juga meningkat.

Beberapa faktor yang mempengaruhi efisiensi HRSG selain dari variasi beban antara lain :

1. Kondisi isolasi pada dinding HRSG

2. Kondisi diverter damper saat Combined Cycle

3. Kondisi pipa-pipa HRSG

4. Kondisi sekat pada HRSG 
Kondisi Combustion Chamber dimana gas hasil pembakaran mempengaruhi efisiensi HRSG.

\section{KESIMPULAN}

Setelah melakukan pengamatan praktik kerja lapangan di PLTGU PT Indonesia Power Semarang PGU pada Heat Recovery Steam Generator di PLTGU blok 2 tambak lorok PT Indonesia Power Semarang PGU, maka dapat mengambil kesimpulan sebagai berikut :

a. Heat Recovery Steam Generator merupakan suatu alat penukar kalor (Heat Exchanger) yang memanfaatkan gas panas sisa GTG untuk memanaskan air menjadi uap kering yang nantinya digunakan sebagai fluida kerja STG

b. Semakin tinggi beban GTG maka semakin tinggi pula panas yang diserap oleh Heat Recovery Steam Generator khususnya High Pressure Heat Recovery Steam Generator.

c. Besar efisiensi HP HRSG pada beban 94MW sebesar 52,07\%, saat beban $80 \mathrm{MW}$ sebesar 49,59\%, dan saat beban 70MW sebesar $48,19 \%$.

d. Semakin tinggi beban GTG maka semakin tinggi pula efisiensi High Recovery Steam Generator.

\section{DAFTAR PUSTAKA}

Anonim. "Equipment Specification For Combined Cycle Power Plant Performance Monitoring No. 510A3061-R578”. GE International Company:Schenectady, NY.

Anonim. 1996. "Operating Manual Heat Recovery Steam Generator Tambak Lorok Combine Cycle Power Plant Block I \& II'. Austrian Energy \& Environment.

Mavendra Dede. 2016 "Kakulasi Efisiensi Daya Mesin PLTGU dengan Pola Operasi 2-21 dan 3-3-1 PT. Indonesia Power UP Semarang. Yogyakarta : Universitas Sanata Dharma.

Priambodo Ady. 2012. "Analisa Efisiensi Low Pressure HRSG (Heat Recovery Steam Generator) pada PLTGU PT. Indonesia Power UBP Semarang". Semarang : Universitas Diponergoro. 